This article has been published in a revised form in Bulletin of the School of Oriental and African Studies https://doi.org/10.1017/S0041977X18001039. This version is free to view and download for private research and study only. Not for re-distribution, re-sale or use in derivative works. (C) SOAS, University of London 2018.

\title{
The Movers of the Text: Monénembo's nomad subjects
}

\section{HANNAH GRAYSON}

University of St Andrews

Hannah.grayson@st-andrews.ac.uk

\section{Abstract}

Transnational African author Tierno Monénembo is known for his unstable narratives and travelling storytellers. In this article I will discuss two of his novels, Pelourinho (2005) and Les Coqs cubains chantent à minuit (2015). Drawing on nomadic thought, the article will argue that Monénembo's lesser-seen subjects are figures of mobile débrouillardise who embody and play out a collective nomadic thinking with which they mediate unstable space. Translation is indirectly addressed here as part of that débrouillard practice, whereby stories, situations, and agency are mediated by these secondary characters. Monénembo translates their wily movement and flexibility into French by keeping mobility at the centre of his structural and linguistic choices. This reading will be framed in an understanding of subjectivity as always conditioned by mobility (after Braidotti), an essential lens for viewing postcolonial African subjects in the era of ongoing decolonisation (Mbembe).

Though written ten years apart, the novels are remarkably similar in their depiction of space and character. Mirrored journeys westwards across the Atlantic seek to draw out the African heritage of lost relations in Latin America. Encounters with multiple, unfamiliar faces are reflected linguistically in the collision of several languages, and I will suggest that where such translingual environments are hostile for some, there is a simultaneous emergence of creativity. This happens both at character level and with the author's own negotiation of different languages and styles. Monénemo demotes protagonists and place to emphasise secondary characters who shape their own space. Drawing on the work of Rosi Braidotti, I use nomad thought to frame these figures as always mobile, savvy, and innovative. This is a positive vision of subjects as dynamic entities, ready to transform, and to translate. 


\section{Introduction}

If, as Achille Mbembe has described it, the African continent "ne se comprend guère hors du paradigme de l'itinérance, de la mobilité et du déplacement" (can hardly be understood outside the paradigm of wandering, mobility and displacement), then our thinking about postcolonial African subjects, both real and fictional, cannot but consider movement (Mbembe 2010: 227). More attention must be paid to the nuance with which this thinking is developed, since there is a risk of classifying subjects by an apparently limiting status, and indeed of viewing migration, or exile, or dislocation, as a determining, and final, 'move'. In such cases, subjects ironically become conceptually immobilised, stuck in a category of 'migrant' (or similar) which is tainted by the pejorative influence of current media discourses of threat and hostility. If rather we take movement as the starting point for these figures, it becomes one important conditioning element, rather than the defining feature, and acts as a springboard for conceptualising affirmative, innovative practices.

This is what Rosi Braidotti achieves in Nomadic Subjects, her exploration of contemporary subjectivity through frameworks of continental philosophy and feminist theory. For Braidotti, nomadic subjects tap into a source of productive power, embodying and enacting an affirmative capacity or potentia, to bring creativity and transformation to their contexts (2011: 12). Building on her poststructuralist interlocutors Gilles Deleuze and Félix Guattari, Braidotti incorporates a discussion of unstable meanings and neglected diversity into her definition of nomadic being. She sees the fluctuating terrain of contemporary cultures worldwide as determining the way subjects experience everyday life, but not in a negative way. Rather, for Braidotti, they are ever-ready to respond to shifting circumstances, and therefore practised at "acting here and now", (2014). This affirmative consciousness will be elaborated in terms of language and space below as I demonstrate how Monénembo's characters negotiate and play with such unstable meanings. The French term débrouillardise, which may be (partially) translated as resourcefulness, helpfully encapsulates such a way of being whilst also carrying connotations of being street-wise. The term is used by citizens of Kinshasa to describe the energy and spirit of survival that characterise everyday struggles in the city, 
and is ideal for describing the spatial practices of Monénembo's subjects (Bayart 1999: 38-9). This is an everyday practice, rather than an oppositional reaction to isolated incidents. Their norm is to move around space, manipulate language, and mediate circumstances to their advantage.

Postcolonial readings of subjects' mobility and the fluidity of language risk being described in overly metaphorical terms as abstracted processes of translation. The metaphorisation of physical movement as translation risks neglecting the material conditions which affect and constrain that movement. Rather, the readiness to move is one part of débrouillardise, which comes alongside an enhanced capacity to translate (stories, situations, and agency). To counter the risk of viewing this form of subjectivity as separate from any real time or place, it is the subjects who must remain the focus, and they must be read as grounded in particular settings. As Rosi Braidotti and Edward Said both underline, homeless people, migrants, exiles, refugees and illegal immigrants, inter alia, are not to be thought of as symbolic wanderers; in fact they live an often violent and perilous existence within highly specific geopolitical and historic locations (Braidotti 2011: 10); (Said 2000: 174). Similarly, any mediation of language and space occurs in specific, material circumstances. These locations and circumstances are properly accounted for via a focus on the unstable conditions postcolonial subjects find themselves in. As I will show, Monénembo's texts provide vivid pictures of the precarious and violent contexts in which these practices are grounded. His pervasive attention to unstable space avoids removing his subjects from where they reside as movers of text.

I suggest that a focus on nomad subjects and the ways they inhabit space reframes postcolonial figures in positive paradigms of innovation and readiness, as opposed to potentially immobilising discussions of race or victimhood. Pelourinho and Les Coqs cubains chantent à minuit, which Monénembo published in 2005 and 2015 respectively, re-focus our attention on lesser-seen characters, who must negotiate unstable spaces.. These texts, like much of Monénembo's work, reveal an innovative débrouillard practice through small acts of mobility as the author illustrates ways to translate movement onto the page. 
Typically Monénembo's narratives are narrated by imperceptible roaming characters, those exiled both locally and transatlantically, and often consider the disrupting effects of dislocation. Importantly, his novels reveal the creative potential that is inherent in moving subjects. Noémie Auzas provides a Freudian reading of Pelourinho (2004: 136; 158), yet this Eurocentric lens overlooks the author's focus on forms of survival which are grounded in local realities. His plots do not detail family histories, nor do they tell Bildungsroman trajectories of character development. Rather, the focus is on how individuals negotiate space in the everyday, forming networks and subverting power structures. Often, as is the case with Pelourinho and Les Coqs, it is Monénembo's secondary characters who prove to be most significant. Just as Lawrence Venuti examines with regards to translators, those who are demoted to second place are left as invisible but are in fact poised for self-reflexive action (1995: 24). The agency of those assumed to be behind the scenes surpasses their degree of visibility. As the narrators of these texts, Monénembo gives his second-place characters the greatest agency. This comes as a direct affront to colonial and postcolonial acts which sought to eradicate the voice of the everyday subject, and is a persistent affirmation that local débrouillards are those with the power to transform the spaces in question. Their tendency to move is essential to this. From prisoners to university students, and villagers to city squatters, his wide-ranging oeuvre foregrounds an entourage of lesser-seen characters. Moreover, now four decades in to his published writing career, Monénembo's texts reveal the ongoing, transhistorical relevance of movement to the postcolonial world. His writing is Francophone and African but also transnational and diasporic, and thus excellently placed to inform any reading of the practices of mediating texts and spaces in this era so marked by mobility. Those on the move inform our understanding of the malleability of space and language and, like translation, highlight questions of what can be adapted and under which conditions. What is more, both mobility and translation shed light on the transfer of power and expression of agency, and the mediation of space and stories more broadly.

The texts under examination here are based in South and Central America, and form part of Monénembo's biographically-inspired oeuvre, which has a notably itinerant fictional setting. Inspired by his own travels in Brazil, Monénembo wrote Pelourinho in 2005. It tells the story of a young West 
African man gone to Bahia (North East Brazil) in search of his roots; he meets a number of local characters; feels disoriented in the unfamiliar space; and ends up dead. The story is told as a posthumous recollection of his time in Brazil.

In a disappointing echo of Pelourinho, ten years later Monénembo published Les Coqs cubains chantent à minuit. This text is set in Havana. In it a young West African man sets out to discover his personal history; he meets a number of local characters; feels disoriented in the unfamiliar space; and ends up banished from the country. And (perhaps unsurprisingly) the story is told as a posthumous recollection of his time in Havana. The number of plot similarities in Les Coqs may raise questions regarding originality, and yet the ways in which the later text imitates Pelourinho point to what Monénembo wishes to emphasise.

First, both protagonists are absent (either dead or exiled) at the beginning of the novel, and have no independent voice in either text; the entire narratives are about them, but not voiced by them. Any speech is indirectly reported by the narrators who retrospectively convey (their version of) what was said. Such a demotion of protagonists challenges the reader's expectation, since the young men whose journeys form the premise of each text are in fact erased to clear the way for others. This is in line with Monénembo's tendency to shift attention away from the main stage of (public) action, to less visible subjects and lesser seen spaces. By removing agency and language from the protagonist, he transfers it to those secondary characters who then narrate the embellished obituaries, demonstrating the potential for shifting power and playing with expectations available to the translator or mediator of a text. It is the language of the narrators, the interpreters of the action, which is most captivating; as indeed is their capacity to stay alive in obviously dangerous settings, and then to creatively weave narratives. As will become clear in my discussion of space, it is typical of Monénembo to take death, or more generally the precarious nature of postcolonial existence, as the starting point for something productive and this is central to nomad thought.

As well as using their death and absence to divert attention from protagonists, in another inversion of the reader's expectation, Monénembo demotes place itself. We might expect Brazil and Cuba to 
appear in Monénembo's texts as exotic locations which lure in visitors. Both of the titular geographical locations certainly seem to hold them up as attractive destinations: as if the position on the cover is an invitation. Indeed both the journeying protagonists head there full of hope and expectation, seeking to discover some sense of belonging. Combined with the optimistic reversal of the slave journey that each protagonist enacts, their hopes for personal fulfilment endow each place with a sense of New World promise.

Both of Monénembo's protagonists end up in a haze of dodgy liquor and backstreet violence; and in this sense the allure of Brazil and Cuba's exotic mixité reveals itself as an illusion. Where the warm welcome of mestiza culture drew them in, hostility to foreigners prevails and they end up killed or banished. The blurb on the Seuil cover of Les Coqs, "Un hymne aux origines africaines de Cuba," (A hymn to Cuba's African origins) indicates a misreading. In fact, illusions like those are shattered and we read mess, confusion, and violence (what Fremi calls "cette île aux vifs contrastes", this island of sharp contrasts, 2016). "Les gens se gourent: ils s'imaginent que La Havane se résume à sa baie, au dôme du Capitole, à la façade du Nacional et aux effigies de Castro. Non, La Havane, c'est El Tosco," (People get it wrong: they think that Havana can be summed up by its bay, the dome of the Capitolio, the front of the Nacional, and the effigies of Castro. No, Havana is El Tosco.) (Monénembo 2015: 178; El Tosco is the local heavyweight). These texts in no way present an exoticised or idealised picture of their settings. On the contrary, Monénembo is demoting place itself, presenting it not as the final destination as the titles' suggestive prominence may indicate, but rather as background and host to the subjects' resilience. Monénembo is concerned with outlining subjects' responses to these spaces, rather than painting a picture of Latin America's vitalizing potential. Any productive energy the author represents lies inherently within subjects, rather than belonging to cities, regions, or nations.

Monénembo could equally be seen to partake in the ongoing reinscription of space and place into different cultural imaginaries, alongside Sony Labou Tansi, and predecessors Aimé Césaire and LéonGontran Damas (Delas 2017). A much earlier traveller, Swiss-born French writer Blaise Cendrars, on travelling to Brazil in the 1920s, found an inspiring mélange of difference there. He saw mestizo 
culture in Brazil mixed with Afro-Brazilian energy as an attractive alternative to the increasingly stifling atmosphere of Europe, and contributed (with his own fictional and non-fictional writing) to the multilingual identity concept which became foundational for Brazil's national identity (See $D u$ monde entier au cour du monde, Le Brésil, des hommes sont venus). Monénembo questions and furthers the transnational movement of concepts, associations, and expectations to do with particular spaces.

Monénembo is to some extent using his writing career to interrogate the place of 'place' in Francophone postcolonial writing. Yet this double take on Latin America is only a temporary draw for the author. His itinerant biography is mirrored in the fictional settings of his work, most recently in Bled in the story of a refugee Algerian woman fighting to protect her child. And in each of his depictions of a migrating figure, there is some lure and some disappointment. It is fair to say that Monénembo is playing with expectations here, by choosing certain titles, then in fact demoting the importance of place both by shattering illusions about that destination, and by relegating its sense (as geographical location) beneath an exploration of space as much broader and more fluid, negotiated and conditioned by the subjects for whom it exists. For instance, on Havana: “c'est une ville volage et exaltée, faite pour ceux qui ont des choses à oublier: les désespérés, les putes, les bandits de grand chemin," (it's a fickle and wild town, made for those with things to forget: the hopeless, the hookers, the highway robbers) (Monénembo 2015: 185).

As it transpires, the destinations announced in the two novels' titles are not the centre of attention, just as the protagonists are not. Rather, Pelourinho and Havana play host to a number of apparently background characters, who act as translators of history, piecing together the backgrounds of the absent protagonists. As those grounded in their local contexts, they have the capacity to witness and narrate the experiences of those arriving from elsewhere. They are the creative innovators who successfully negotiate these cityscapes, knowing their own agency and the lie of the land. As Monénembo reveals, it is not warm and welcoming, but precarious and ever-shifting. 


\section{Journeys}

Monénembo's journeys are not all large-scale or international, and always emphasise the everyday moves of normal characters. . In these novels, protagonists Escritore and El Palenque travel across the Atlantic Ocean to Bahia and Cuba respectively, and these transatlantic journeys stand as an important motif in both texts. Despite the demotion of place explained above, the significance of the journey motifs is considerable. It can be outlined in three ways.

First, as the foundation of each novel, the westbound transatlantic journey removes Europe somewhat from the equation, presenting alternative dream destinations to the metropolitan centres of Paris or London. Travelling away from the West undoes the superlative connotations of that term. This moves Francophone postcolonial writing out of self-other binaries (such as France/Africa) and provokes questions about how other others relate in the global south; not separate from Europe (the main language of both texts is French), but without Europe as centre. Elsewhere, in Un Rêve utile (1991) and Un Attiéké pour Elgass (1993), Monénembo's characters long for France as an ultimate destination; here Europe is not even a desired endpoint. Really, the author undoes any sense of seeing hope fulfilled in a final destination when Brazil and Cuba see the protagonists killed or expelled.

What is more, this kind of journey undoes the centrality of racially-centred identity quests which might go "back to Africa". Instead of a village-based retrospective (which Monénembo writes with Cinéma (1997), in the vein of Camara Laye's L'Enfant noir), these protagonists challenge Afrocentrist frames which insist on a return to a single point of, racially-based, origin. "Un Africain à Cuba à la recherche de ses racines ! C'était bien la première fois que j'entendais ça. En temps normal, c'était l'inverse qui se produisait." (An African in Cuba in search of his roots! It was certainly the first time I'd heard that. Usually it was the other way around.) (Monénembo 2015: 27). Additionally, belonging in any hereditary or racial sense is complicated in the mixité of the Cuban and Brazilian contexts, and in El Palenque's own mixed heritage. No exotic notions of rainbow nations are sustained, since outsiders are ultimately shown to be unwelcome. The identity quest remains but a premise, one that is sceptically treated by all other characters, and indeed Monénembo's effacement 
of both protagonists before each novel begins reveals such journeys as futile and in one case fatal. The irretrievability of family unity is underlined in broken relationships elsewhere in the texts, Auzas (2004: 153).

Thirdly, these journeys are opted-for. In their contemporary re-tracing of the Middle Passage, they scribe new kinds of movement dissociated from slave history. These are not enforced transatlantic journeys but voluntary quests which do not stem from positions of victimhood. Via this choice, Monénembo underlines agency; and yet there is no illusion of complete freedom of movement, given the hostility which characterises the space. Nevertheless, this emphasis on creative agency is evident in Monénembo's chronological development away from dictatorship literature, where characters were imprisoned in claustrophobic and a denser style in Les Crapauds-brousse and Les Écailles du ciel. His shifts in style see Pelourinho as more experimental than his earlier work, indicating the playful débrouillardise of his hidden figures.

In summary, the significance of both transatlantic journeys is in what they highlight, how they point a reader to appreciate certain characteristics and what is at stake in translational shifts. In these choices of setting we see hints of what a focus on nomadic thought can bring to African literature: first an interrogation of what Europe means to postcolonial African subjects; secondly, a move away from race-centred representation of identity; and thirdly, taking innovation and agency as a baseline for understanding postcolonial subjects. Postcolonial readings of movement and mobility also have much light to shed on questions of language: namely how the above ideas are given textual form, and in multiple languages. The same attention we give to mobile subjects is also due to meanings and associations, which are contested and constrained in similar ways. Addressing space and language together also raises questions of how we might look beyond borders and beyond hostile and immobilising processes of othering to focus instead on points of confluence and negotiation. These in turn, as it transpires in these two texts, come with their own likelihood of contestation and even 
failure, as with any translational process or encounter, and are best negotiated by those who know the territory.

\section{Unstable spaces}

Postcolonial scholarship has considered the terminology and tropes of movement at length, for instance specifically in women's writing (see Averis and Isabel Hollis-Touré 2016), and in relation to global conflicts (see Roland Hsu 2010). Equally, fruitful discussions have assessed the relationship between processes of translation and mobility, and how these are reflected in literature. For example, how a writer's own journeys can be reflected in the literature she produces which, when translated, can perform a kind of linguistic hospitality, "helping literary texts to escape the confines of the national borders from which they have emerged to enter other contexts, [to promote] intercultural exchange" (Tadjo and Batchelor 2013: 100). But little attention has been given to their everyday contexts, or the small acts of mobility which might indicate a mindset of resilience in nomad subjects. Here, these contexts in Monénembo's texts provide a rich corpus to take Braidotti's work forwards. In order to explore further these ways of being which are affirmative, and which do not depend on fixed identity categories for instance of race or victimhood, specific supplication of nomad thought to linguistic and spatial dexterity is required. This will allow us to acknowledge more comprehensively the experiences of moving subjects, and to account for their agency as mediators and creators.

I come now to the unstable spaces in these texts, then in turn to the mobile subjects who inhabit them. Throughout this reading, their creative débrouillardise will be brought to the fore, and contextualised in its precarious postcolonial setting. Here it is important to avoid too great a focus on any particular "third space" (Bhabha 1994) since this can lead to seeing the space as autonomously productive. It is more important to look at more common everyday spaces, and how these are negotiated ongoingly by nomad figures. We might look to the bar, street, town square, or home as good examples.

What transpires across Monénembo's oeuvre is that spaces are unstable. Often, political and racial tensions feed into a prevailing sense of instability where corruption and hostility emerge in violent outbursts. The microcosmic insecurity which characterises the novels' spaces both reflects and is 
linked to the larger instability of history for African subjects, Auzas (2004: 31). Where Auzas rightly observes that "les personnages sont soumis à une insécurité quotidienne" (ibid), she does not acknowledge that this remains, fatally, unknown to naïve outsiders. This everyday insecurity is not obvious at first sight. The lure of family roots and warm climes that draw Escritore and El Palenque over the Atlantic fades as they encounter the unfamiliar: dangerous, hazy, and foreign-seeming city space.

Monénembo perpetuates this sense of unstable space by casting a blurry haze over the physical settings in each novel. This is in part due to one of the narrators, Leda's, blindness, and the darkness announced in the title of Les Coqs, but is spread more generally around the bars where the stories are narrated, Lluvia de Oro in Les Coqs and la Cantina da Lua in Pelourinho (both referring to light through reference to gold, and the moon). The shadiness of these places stems out into an alcoholinduced opacity further afield, as Ignacio describes:

À la Lluvia de Oro, je savais que je devais juste t'accompagner, qu'au cinquième verre, déjà, tu ne serais plus là, comme disparu derrière un virage alors que ton corps se reflétait sous mes yeux, proche mais blindé, inaccessible, terriblement dissuasif. Et avec le rhum qui me brûlait l'esprit, avec le bruit de la musique et des verres, ta tête n'était plus qu'un simple masque de citrouille baignant dans le bain mauve des lumières (Monénembo 2015: 183-4).

(At Lluvia de Oro, I knew Ijust needed to stay with you, that by the fifth glass you'd already be gone, as if disappeared round a bend while your body was mirrored before my eyes, close but shielded, awfully offputting. And with the rum burning my mind, and the noise of the music and glasses, your face was no more than jack-o'-lantern soaking in the mauve bath of the lights.)

Similarly, the city space of Monénembo's Salvador in Pelourinho is permeated with the smell of alcohol, which "renforce l'aspect incertain, dangereux du monde", Auzas (2004: 34) Mãe Grande’s bar carries the stench of cachaça, and the heat of the sun makes walking from place to place an ordeal. Palito, Careca, Passarinho and Preto Velho sit at the bar for hours trying to forget their jobless states, and listening to Innocencio question Escritore, all beneath the heavy smoke of their cigarettes (Pelourinho: 62). Often drunk, characters' sway from place to place, unsteady on their feet as they wander blurry-eyed through the streets of Pelourinho, adding to the risk of wandering around the neighbourhood's dark corners. As savvy local Ignacio warns early on, "plein de tuiles peuvent arriver à quelqu'un qui aime La Havane la nuit et qui ne fait pas trop attention à ce qu'il boit," (a lot of bad 
luck could come to somebody who likes Havana by night and doesn't pay too much attention to what he drinks) (Monénembo 2015: 33).

Pelourinho and Les Coqs are not Monénembo's most disorienting texts as far as reading is concerned, but give a taste of the dizzying effects he evokes in more exaggerated attempts elsewhere (see $U n$ Rêve utile). Monénembo's translation of this sense into language relies here on a highly descriptive style. What is distinctive about the atmospheres created in these two novels is the use of imagery connected with the natural world: as well as the play of dark and light, and the persistent presence of alcohol, water plays a central role. The coastal positions of Havana and Salvador mean there is a constant reminder of where the protagonists have come from. And simultaneously the Atlantic stands as a reminder that their journeys are open-ended, and that return is always looming. In Leda's narrative, flashbacks of a slave being tortured wash in and out of her monologues like waves: they leave traces of the past but disappear, incomplete. The connotations of lost life and stories in slave history are obvious, and in some sense the looming, moving Atlantic perpetually denies Escritore the possibility of realising his naïve intentions (here cited by the sceptical Innocencio):

Je suis venu animé d'une vocation: emboîter le pas aux anciens, rafistoler la mémoire. Je vais faire œuvre de moissonneur: ramasser les éclats, les bouts de ficelles, les bricoler et imbriquer le tout. Je veux rabibocher le présent et l'autrefois, amadouer la mer (Monénembo 1995: 150).

(I have come driven by a calling: follow on the heels of the Ancients, patch up memory. I am going to do the work of a reaper: gather up the fragments, the bits of string, to mend them and fit it all together.)

The author's use of natural imagery includes a breeze which blows through Havana and Salvador streets. As with liquid (alcohol, water), the impermanence of wind is significant. The murmuring of rumours is symbolised by mist and wind, again emphasising the ephemeral and intractable nature of memory and history. Neither protagonist remains to piece together the fragments of the family story they come seeking, and generous use of ellipses in both novels drives this home. For Monénembo, history, and understanding it, will always contain contestation (the contrasting and violent narratives) and omission (signalled by ellipses and incomplete conversations). In placing death and absence at the very heart of these two narrative memorialisations, Monénembo overtly states that there will always be some silences, uncertainties, and amnesia. Elements of the natural world are intensified so as to 
cover the texts, creating mists between plot and reader, and between locals who translate the opacity into advantage, and the foreigners who seem unable to. The themes of clairvoyance and opacity emphasise the distinction between the débrouillard locals who negotiate the hazy unpredictability of space, and those who are disabled by it. There is something defiant about the opacité which hangs in these spaces, presenting a Glissantian insistence on untranslatability for those from elsewhere. What is clear for Monénembo is that the mediation of story, sense and self is dependent on the creative capacities of subjects, rather than on any energy or possibility inherent in a place. Silences and failures show that negotiating space, language, past and present will not always be possible, and will not be a possibility for everybody. Translational processes are prone to (partial) failure, due to the complexity or depth of a source space or text, and its lack of an equivalent, rendering it somewhat untranslatable. However, they simultaneously present concrete possibilities for interrupting the master narrative, possibilities which are always dependent on "varying cultural assumptions and interpretative choices, in specific social situations, in different historical periods", (Venuti 1995: 18). Those with enhanced capacities for débrouillard innovation and fluidity are best placed to confront such opacity and engage in the necessary processes of adaptation and compensation.

A dizzying soundscape adds to the sense of unpredictability. In Les Coqs, music fills the pages, at times almost drowning out any story. The atmosphere in the Lluvia de Oro bar is a heady mix of hits by Aguas del Guaso and the clink of glasses being refilled with rum. It is, quite literally, a place for drowning sorrows, "il te faut des bars, des bordels, de la musique, du bruit" (you need bars, brothels, music, noise) (Monénembo 2015: 183). National histories and personal memories emerge in both texts in snippets of a song. As Ignacio explains:

Notre musique ne fait pas que rythmer les pas de danse, elle rythme aussi la cadence de l'histoire... Ses chansons contiennent tout : la saga des villes, l'odyssée des plantations, les idylles sanglantes, les expéditions rocambolesques et les révolutions interminables. À chacun sa manière de se tourner vers le passé. Ailleurs, on fouille les archives ; ici, il suffit de quelques vocalises (Monénembo 2015: 94).

(Our music gives rhythm not only to dance steps, but also to the beats of history...Its songs contain everything: the saga of cities, the odyssey of the plantations, violent idylls, incredible expeditions and unending revolutions. To each his own way of facing the past. In other places people search through archives; here it only takes a few songs.) 
Monénembo's writing in these scenes integrates rhythm as an essential element, again similar to his Négritude predecessors Césaire and Damas whose rhythmic expression of black culture is excellently examined by Martin Munro (2010: 134-142). This busy soundscape is heightened by the coexistence of different voices and languages. In Pelourinho there is a dual narrative structure, where two characters take turns in recounting Escritore's life: Leda, an elderly lady, and Innocencio, a streetwise man. This alternating of chapters between a blind octogenarian and a woozy wheeler-and-dealer produces a disorienting effect through the text's see-saw form. As well as structure, this comes from their contrasting personas and variation in language. Specifically, their register and lexis are ever shifting, but also volume, with whispers and shouts patching together some semblance of a posthumous eulogy. The dizzying effects of wandering lost around the labyrinthine neighbourhood are conveyed in the state of intoxication which hangs over the text; and Innocencio's verbose and slurry speech often belie his heavy drinking in unfinished sentences (Monénembo 1995: 143). For her part, Leda's confused mental state and broken stories are conveyed to the reader through unsteady and heterogeneous passages of prose, as Monénembo inflects her narrative with hesitation, repetition, reported dialogue and song, creating a winding story not easy to follow. Equally, there are sharp changes in narrative pace as threats of conflict and the hunger for money create a consistent forward movement in Innocencio's narrative. Then violent interludes interrupt the narrative flow causing structural rupture in the text; at a basic textual level leaving paragraphs incomplete, and chapters broken. Leda's voice generally speaks much more slowly, and her enigmatic account in particular creates hanging suspense through the profusion of ruptures and silences, most notable when she recounts the birth of her son. Her mind wavers from memorised to imagined scenes, leaving sentences unfinished with gaps that stand indicate her trauma in the shortest passages of the whole novel (Pelourinho: 188-193).

Where the newcomer protagonists struggle in these soundscapes, and trip up over unfamiliar words, the secondary characters have no trouble. Multilingual, busy soundscapes do not deter the locals in any way, but form a diversion or fun, creative detour. Their resourcefulness extends to neologising, codeswitching, and the mixing of registers, and their exploitation of the fluidity of language 
demonstrates the possibilities maximised by those who belong in the mestizo spaces of Brazil and Cuba. These rooted-but-mobile locals are best equipped for translational encounters, enacting agency through name-giving, and standing their ground as authorities for these spaces. As an example, in Pelourinho, Innocencio nicknames the visitor Escritore (the name I have used in this article), each time deriding him for the naïve intention to scribe his family history. Leda, in turn, calls him Africano, as a repeated signal, perhaps, of where he really belonged. In Les Coqs, Ignacio addresses the protagonist as El Palenque, a nickname either referring to his stocky figure (palenque is a hitching post or fence in Spanish) or to his outsider status (Palenque was also a city in southern Mexico). Thus we see the secondary figures mediating language to tease, and to highlight identities they have attributed. Their playfulness disguises and exemplifies their power to name, and the transformational capacity inherent in such naming.

Another way Monénembo's literary writing mirrors the innovation and movement occurring in his fictional spaces is, in both texts, through the somewhat frictional presence of multiple languages: French, Fulani, English, Yoruba, then Portuguese, Spanish and Creole all brush up against one another. In the melting pot of Salvador, Escritore brings his West African French into a Lusophone city where the street talk also happens in Yoruba and English. In Havana, Monénembo has Ignacio write the novel-letter to El Palenque in French, against a backdrop of Cuban Spanish inflected with fragments of an incomprehensible song. All this linguistic moving between means the soundscape never seems still, and adds to the sense of space being unpredictable and thus precarious. The linguistic dexterity of local subjects illustrates their agency, but also the practised débrouillardise which comes from inhabiting these multilingual spaces long term (unlike the newcomers who remain mute). By subverting, diverting, and wending his linguistic way around multiple languages, Monénembo maps nomadic movement onto the pages of these two novels, showing himself to be a negotiator of postcolonial space and language, much like those in his texts. 


\section{Nomad subjects}

So we see that instability in these cities persists, like that described by Abdoumaliq Simone as a condition of African cities in the present time, where conditions like the ones I have just described "keep residents in an almost permanent state of changing gears and focus, if not location" (2001: 16). The focus on people moving goes beyond the transatlantic journeys that Escritore (in Pelourinho) and El Palenque (in Les Coqs) make. Where these act as both novels' premise, perpetual small-scale movements at a local level make up the heart of both texts and provide the energy which propels the plots along. The local characters are accustomed to moving around where they are, and thus undermine the newcomer protagonists' determined quests to "rabibocher le présent et l'autrefois" (to reconcile the present and the former times) (Pelourinho: 150), along with any understanding of a defined subject as coming from one place and going to one other. In their mediation of space and language, they are the movers of these texts. The significance of nomad thought here is less to do with increased travel in a globalised age, or historical transatlantic movements, and more relevant for how the dynamics of displacement and power engender a mindset of creativity and débrouillardise. This is visible, and strengthened, in the everyday movements of lesser-seen characters across Monénembo's oeuvre; these are the savvy locals who are practised at negotiating the kinds of spaces which are dangerous, hazy, and full of noise. This kind of practical wisdom positions these characters as translator figures, ever informed and nimble. It differs from a well-informed or abstractedly intelligent consciousness in that it is highly practical. Subjects learn by living through the selfperpetuating vicissitudes outlined in these novels. The emphasis Monénembo places on stark circumstances only strengthens the representation of these subjects' agency. Here, the centrality of the jarring and problematic term "négraille" as subject of the verbs which follow shows these subjects are far from backgrounded victims of History:

La terre pourrait s'ouvrir, le monde de décrocher... Mille fois tournée et retournée dans le fournil de l'Histoire, la négraille avait appris à se faire à tout. Elle savait flairer la bourrasque du pire, savait l'attendre, le corps faussement vacillant, mais les pieds comme des souches dans la terre ferme (from Monénembo 1986: 158). 
(The earth could open up and the world fall away...Turned and turned around a thousand times in the bakehouse of History, those blacks had learnt to do everything for themselves. They knew how to sense the worst, coming on the wind, knew how to expect it, their bodies pretending to sway but their feet like stumps on solid ground.)

The rootedness in (albeit unstable) space, matched with the ability to move as needed, equips them as débrouillards. Innocencio, for example, makes himself employable by facilitating the wishes of the wealthy. For instance, his involvement with Escritore comes about when he agrees to help him find the common descendants of his mystical ancestor, Ndindi-Grand-Orage. Similarly, Ignacio does supposed favours for foreign visitors in Les Coqs, in return for payment. His situation, we discover, is constrained by a debt he owes to local henchman, El Tosco, and he lives and works under the direction of his gang.

Ton rôle, m'ont-ils dit, c'est de fouiner dans le quartier, d'écouter aux portes, de hanter les ruelles et les bars et de nous rapporter fidèlement tout ce que tu vois, tout ce que tu entends. Comme couverture, on t'offre un job de jardinier au parc Maceo (Monénembo 2015: 179)

(Your job, they told me, is to search through the neighbourhood, listen at doors, to haunt the alleyways and bars and to report to us faithfully everything you see, everything you hear. As cover, you'll get a job as a gardener in Maceo park.)

The under-cover (and somewhat sinister) nature of Ignacio's activities, and his readiness to be on the move and always informed, is typical of Monénembo's nomad subjects. At no point in the text does he describe himself as nomad, criminal, or anything else, but instead tells stories of former exploits and encounters. This is the same for Innocencio, and is worth mentioning, since Monénembo's presentation of local, lesser-seen subjects is about practices rather than identities, more about what can get done. There is a parallel again with Venuti's account of the effacement of the translator's identity, where the latter's focus is (necessarily) on engaged action and the potential inherent in the process, rather than on self-promotion (1995: 19). If translation is considered a "second-order representation" then the personality or intention of the translator is considered equally irrelevant (1995: 6). In this way, nomadism here avoids becoming an abstracted notion used by an educated elite for self-stylization and self-celebration. This is what Dick Pels warns against in his article, "Privileged Nomads":

Construing the migrant, exile or nomad as alter ego of the modern intellectual, or beyond this, as a privileged metaphor for modern subjectivity, often leads towards an intellectualist domestication and appropriation of the experiences of "real-life" migrants or exiles, while 
it simultaneously euphemizes the comparatively settled, sedentary and privileged situation of academics, who are invited to indulge fictions of social "weightlessness" and dreams of perpetual transcendence in boundary-breaking journeys of the critical mind (1999: 72).

By contrast, the attention given to precarious and dangerous space in Monénembo's novels means his characters are always grounded in real, material and lived nomadism. This shows nothing of the disembedded nature of Universalism criticised by Braidotti, but is rather located in "spatiotemporal and geopolitical specificities" (2011: 129). The violence and economic urgency they face means the focus is on wily tactics for survival, rather than self-identification, just as the translator is focussed on productive processes and not on self-promotion. Hence, writing on mobility in postcolonial criticism must refrain from focussing on processes of self-designation, and instead attend to framing ways of being. Movement, as I am arguing here, is one overlooked feature but it must not become the defining feature in a way that might suggest subjects consciously self-describe in these terms. Rather, it must be factored in alongside social and political contexts, and dynamics between other subjects. This is where the dialogue form of both narratives is an elucidating example of nomadism-through-language which is not addressed by Braidotti.

The resilient and creative débrouillardise of Monénembo's African subjects is never enacted autonomously. Braidotti focusses on the symbiotic engagement of multiple others in this kind of rhizomatic mode (Deleuze and Guattari, 1988): in these texts the inventiveness emerges in making friends, connections, and money, but it might elsewhere be establishing home and belonging in new ways. Nomad subjects will be attached to multiple communities, and their home and sense of belonging will be composed in the encounter with others, often reconfigured, Braidotti (2011: 11). This multiplicity extends to a range of cultural materials which remain, as for translators, at their disposal (Venuti 1995: 21). Through repeated dislocations, in becoming nomadic, one learns to reinvent oneself. These processes are part of a collective readiness to negotiate discontinuities in translational processes, and the clash of familiar and unfamiliar in Unheimlichkeit, but such readiness is obviously (and fatally) absent in those less practised. Escritore and El Palenque, trying to go it alone, and without knowing the lie of the land, cannot make their way, nor trace the roots they so desire. 
Within these networks, characters use one another to spin stories. For instance, in Pelourinho Leda fills in the gaps left by Innocencio's alternate chapters; as they move the text from one to the other, it takes shape. Though her vision is impaired, and the space around her crowded, she is not prevented from gathering together fragments of the past and present in creative narrative: "Certes la chambre où je vis est emplie de remugles, de cafards et de guêpes, mais c'est un vrai projecteur: je capte tout, moi, Leda-paupières-de-chouette, toutes les images émises par les vivants et par les morts" (Yes, the bedroom I live in is full of mustiness, cockroaches and wasps, but it's a true projector: I catch everything, I do, Leda-with-owl-eyes, all the pictures sent out by the living and by the dead) (Monénembo 1995: 124). Auzas describes Leda as victim to a traumatic past (2004: 135), but this downplays her agency. Her own dexterity, as well as Innocencio's symbiotic engagement, allows her to interpret history, translating Escritore's past to the present. Hence we see the creativity as well as the transformative power which lies in nomadic practice. In a way, the texts' transatlantic moves also symbolise such power. By not focusing on the historical moments and seismic injustices of slavery, Monénembo enables Africans on the Atlantic to be dissociated from the Middle Passage. They are the movers of texts in that they shift the master narrative away from victimhood and towards agency. As the protagonists re-trace the journey, they are not themselves rooted in or bound by it; they are connected to the past, but agents who shape their own stories in the present, and remain unperturbed by the "fragments arrachés" (snatched pieces) of the story's labyrinth (Glissant 1990: 83).

Parallel to the mediating of language seen above, nomad subjects are also innovative in their spatialising practices. The two are inextricably linked, which renders Monénembo's literary translation of their small acts of mobility even clearer. The proliferation of locations in these novels highlights this, since where a sense of dizzying tension is created, the locals are well-accustomed to it. In Pelourinho, we are led from le bar, la rue principale, (the bar, the main road,) la praça... behind closed doors to Leda's lair, all via les ruelles zigzagant (the zig-zagging alleyways) which make up the labyrinth that is Pelourinho, the eponymous district of Salvador, capital of Bahia. In the same way in Les Coqs, the locals' movements are characterised by detours and diversions where protagonist and reader just seem to gain a grasp of what has happened (in the past) as it slips out of reach or 
disappears. It transpires late in the text that El Palenque has been banished from the country because the authorities were suspicious of his snooping. In contrast, the narrator-locals meander without trouble, and with an ever-pragmatic, and often sceptical, tone.

The short length of each scene and the omnipresence of movement lexis drives home their perpetual, savvy motion. Conversations happen in passing, and the reader's attention is diverted from past to present by the continual, quickly changing focus. Anecdotes are told in pieces: interrupted and continued later elsewhere. The following selection of vocabulary, from just a few pages of Pelourinho, gives an indication of how locals weave around the city in a peripatetic mode:

traversais, échapper, venir, montèrent, partis, accompagnait, s'agiter, quittée, tomber, réapparaisse, traverse, tourner, sort, danse, apparait, marche, sortir, remonte, s'approche, rentrer, faut-que-je-parte, lève-toi, reviendrais, monter, tomberai, en-traversant, m'agripper, parviendrai, pousse, l'enjamberai, défiler, envahissant, venait, tourna, agitant, plongea-en-transe, t'enterrer, traverser-la-mer, marcher, quittés, retrouver, ailles-seul, remontant, croisé (Monénembo 1995: 97-102)

(crossed, escape, come, went up, left, accompanied, hurry, left, fall, reappear, cross, turn, go out, dance, appear, walk, go out, go up again, get close, come back, I've-gotta-go, get up, come back, go up, fall, crossing, cling on, reach, push, step across, unwind, invading, came, turned, waving, fall-into-a-trance, bury you, cross-the-sea, walk, left, meet, goalone, going back up, crossed)

The narrative is a blur of comings and goings, through which the reader tries to decipher certain secrets. Yet the reader's disoriented ignorance comes in contrast to the savvy secondary characters who disclose and conceal information at their leisure. In Les Coqs, stories are told on the barman's terms, and in Pelourinho, Leda's recollections are weaved according to her unpredictable flashbacks and ephemeral descriptions. When stillness and silence do occur, they stand out as rare points of stasis.

Building on her interlocutors Deleuze and Guattari, Braidotti describes nomadic thought as a kind of critical consciousness that resists settling into socially-coded modes of thought and behaviour. Moving behind the scenes, and diverting away from the norm, seems to be at the heart of it. As Braidotti puts it, "consciousness-raising and the subversion of set conventions define the nomadic state," (2011: 26). Nomad subjects tap into a source of productive power and enact an affirmative capacity to transform and mediate their contexts - and these include the contexts of instability and 
danger I have described above. The kind of creativity which emerges might be linguistic, and it might also be geographic, as in the ways of dwelling in and moving around space indicated above.

I match this capacity for creativity with mobile débrouillardise and suggest these together form the basis of a collective nomadic mindset, or kind of cultural imaginary, traceable across Monénembo's texts. The mobile part should already be clear. Subjects mediate space and self as translators on the move, who also inhabit shifting terrain. As Ignacio concludes of El Palenque, "Cuba a laissé des traces en toi. Des traces floues, mouvantes et désordonnées impossibles à interpréter, impossibles à oublier," (Cuba left its trace in you. Vague traces, moving and muddled, impossible to interpret, impossible to forget) (Monénembo 2015: 174).

The débrouillard (or resourceful) element in short refers to the readiness and ruse common to nomad subjects. Be they migrants, pickpockets, or barmen, these figures possess heightened awareness, and commonly an accompanying tone of pragmatism, as we have seen. This could emerge in wily attaining of food, an ease in socially mixed company, or other more morally ambiguous activities. The common traits are a confident and savvy approach to meeting challenging situations with inventiveness, readiness, and mobility. And an informed awareness, which is where Escritore went wrong: his death is blamed somewhat on his naivety: "Ton erreur fut ton optimisme excessif. Il ne sert à rien de prendre sa vie pour une recette de cuisine avec ce que cela comporte de choix, de cohérence, de programmation," (Your mistake was your excess of optimism. It's useless to treat your life like a recipe, with its choice, coherence, and order) (Monénembo 1995: 197). He lacks the street wisdom of Innocencio, who occupies the apparently inferior but in fact informed position of narrator. The ability to be ready for anything seems to develop on consistent exposure to the vicissitudes of this kind of space. Citing Braidotti again, "the different becomings are lines cutting open this space and demanding from us constant remapping: it is a question, every time, of finding new coordinates," (2011: 31). The way Monénembo foregrounds such débrouillard figures demonstrates his commitment to finding new coordinates with which to frame postcolonial subjecthood. 
The clearest embodiments of this commitment in Monénembo's work are in his characterisation of lesser-seen characters, the proponents of a kind of lucid street expertise who mediate space and language. These are those streetwise stand-in teacher-figures, who are more covert than griots, and less conspicuous than protagonists. They are the ones who translate past to present and are the mouthpieces for the stories we read. These secondary characters present clear examples of the selfstarting resourcefulness typical of nomad subjects, and the transatlantic newcomer protagonists appear as novices alongside their débrouillardise. As the ironically named Innocencio discloses, "moi, je mise sur la défaillance des autres, je vis de leurs erreurs," (as for me, I bank on the weakness of others, I live off their mistakes) (Monénembo 1995: 198). The capacity to negotiate local knowledge, withholding it from outsiders and mediating it as desired, is one example of this in both texts. As Ignacio explains, with unabashed pragmatism, “il n'y avait là rien de philanthropique” (there was nothing philanthropical about it) (Monénembo 2015: 175).

\section{Conclusion}

Understanding the importance of movement is essential to contextualising African thought, and postcolonial scholarship, in the transnational age of heightened mobility in which we live and write. It has implications for our thinking about processes of all kinds of spatial, personal, textual, and linguistic mediation. "It comes down to a double consciousness of both the multiple axes of oppression, and hence of hurt, humiliation, and pain, as well as the creative force they can generate as motors of transversal and collective transformation," Braidotti, (2011: 32). Hence the relevance of writers like Monénembo, who emphasise the unsteady and dangerous contexts of postcolonial space, whilst also scribing the multiple ways characters inhabit them with resilience and creativity. Again the author's use of the bar as a place where characters retreat is a helpful example. Here they can speak freely (tongues loosened by drink), away from the gaze of official authorities. It fosters "double consciousness" (Braidotti; Gilroy) by being a site to share stories of suffering, and equally to be buoyed towards change. Postcolonial reading must move beyond Afro-pessimist readings which emphasise instability at the expense of agency. In other words, we must simultaneously ground subjects in the instability and violence of their contexts (or in Mbembe's "grande nuit" 2010) whilst 
looking to the creative production (of senses of self, of spaces, of belonging) which goes on there. In translational terms, we must attend to all that is contested and untranslatable, whilst seeking textual and linguistic encounters which are innovative and productive.

As I have demonstrated, these spaces are not accessible to all. The disorienting, maze-like space of Pelourinho, and the hostility of Havana thwart the outside visitors who naively claim to belong. The incoming protagonists' newcomer status highlights the savviness of the locals, and their capacity to manipulate and shift space and language with ease. Sympathising with the former, we as readers are left to negotiate sentences which are elongated and hard to grasp, and are thrown off track by unfamiliar words and unfinished stories. In this sense, the linguistic and structural features of the text imitate the precarious spaces they describe, and enact foreignization throughout the texts. Together with use of light and dark imagery, as well as symbols of water and wind, Monénembo effectively translates the physical into the textual, and evokes disorientation and a sense of alienation such that concepts of place need to be revisited. Space, it transpires, is unstable and unpredictable, and the territory of débrouillard figures who are more nomadic than fixed categories of victimhood might suggest.

The echoes in Les Coqs cubains chantent à minuit of Monénembo's intentions in Pelourinho are worth noting. Both his erasure of protagonists to give way to the secondary characters, and his relegation of place to the title pages, places the emphasis on true survivors, who are remarkable in their capacity to thrive and to mediate the spaces they navigate. The demotion of place enacts a creative overcoming of the colonial process by reinstating the agency and importance of local subjects. The novels' foundational transatlantic journeys are significant as motifs which place a question mark over Europe, race, and agency, and thus contribute considerably to Monénembo's reframing of postcolonial African subjecthood. The unstable spaces he depicts convey the precariousness and potential danger of local contexts, but these do not trap local figures in positions of victimhood. Instead, these wily débrouillards navigate the conditions of instability to their advantage, and in their own everyday acts of mobility mediate space and language to demonstrate affirmative ways of being: they are the movers of the text. 
My conclusion here is that nomadic frameworks can help African thought account for these traits and show that out of unstable, multilingual, diverse, dynamic spaces emerge productive practices which include the formation of re-grounded identities, new senses of space and belonging, and linguistic dexterity. Where alterity is hosted effectively, there is scope for creativity and innovation. By playing with our expectations, these texts focus our attention on the negotiation of space by lesser-seen characters, or Venuti's invisible figures. Monénembo's translation of nomad subjectivity into novelistic form provokes a re-framing of postcolonial subjects which places mobility at its centre. Whilst not devaluing or neglecting the material circumstances among which these figures move, he posits potential constraints and limitations as creative opportunities, in order to attribute to his fictional subjects a productive imaginary which is manifested in a series of débrouillard practices. As with translation, these potential sticking points are opportunities for negotiation and agency. Monénembo's fiction is an excellent place to start examining how the dynamics of movement and mobility can lead us to re-frame postcolonial subjects in terms of creativity and resilience. 


\section{List of works cited}

Auzas, Noémie. 2004. Tierno Monénembo: Une écriture de l'instable. Paris: L'Harmattan.

Averis, Kate, and Isabel Hollis-Touré (eds). 2016. Exiles, Travellers and Vagabonds: Rethinking Mobility in Francophone Women's Writing. Cardiff: University of Wales Press.

Bayart, Jean-François, Stephen Ellis, and Béatrice Hibou. 1999. The Criminalization of the State in Africa. Oxford; Bloomington: Indiana University Press.

Bhabha, Homi. 1994. 'DissemiNation: Time, Narrative and the Margins of the Modern Nation' in Homi Bhabha, The Location of Culture. London: Routledge, 139-70.

Braidotti, Rosi. 2011. Nomadic Subjects: Embodiment and Sexual Difference in Contemporary Feminist Theory. New York: Columbia University Press.

--, "Thinking as a Nomadic Subject." 2014. Lecture given at the Berlin Institute for Cultural Inquiry, 7 October.

Cendrars, Blaise. 1987. Du monde entier au cœur du monde: poèmes. Paris: Denoël.

--, Le Brésil, des hommes sont venus. 1987. Fontfroide-le-Haut: Fata Morgana.

Delas, Daniel, (ed.) 2017. Afrique - Brésil, Etudes littéraires africaines 43.

Deleuze, Gilles and Félix Guattari. 1988. A Thousand Plateaus. Trans. Brian Massumi. London: Athlone.

Fermi, Elena. 2016. "Tierno Monénembo, Les coqs cubains chantent à minuit", Studi Francesi, 179, 374-375.

Gasster-Carrierre, Suzanne. 2016. "Review of Monénembo, Tierno, Les coqs cubains chantent à minuit", The French Review 89/4, 270.

Gilroy, Paul. 1993. The Black Atlantic: Modernity and Double Consciousness. London: Verso.

Glissant, Édouard. 1990. Poétique de la Relation. Paris: Gallimard.

Hsu, Roland (ed.). 2010. Ethnic Europe: Mobility, Identity, and Conflict in a Globalized World. Stanford: Standford University Press.

Laye, Camara. 1953. L'Enfant noir. Paris: Librairie Plon.

Mbembe, Achille. 2010. Sortir de la grande nuit: Essai sur l'Afrique décolonisée. Paris: Découverte.

Monénembo, Tierno. 1979. Les Crapauds-brousse. Paris: Seuil.

--, 1986. Les Écailles du ciel. Paris: Seuil.

--, 1995. Pelourinho. Paris: Seuil.

--, 2015. Les Coqs cubains chantent à minuit. Paris: Seuil. 
Munro, Martin. 2010. Different Drummers: Rhythm and Race in the Americas. Berkeley and Los Angeles: University of California Press.

Pels, Dick. 1999. "Privileged Nomads: On the Strangeness of Intellectuals and the Intellectuality of Strangers", Theory, Culture \& Society, 16/1, 63-86.

Said, Edward. 2000. Reflections on Exile and Other Literary and Cultural Essays. London: Granta.

Seydou, Christiane. 1988. “Epopée et identité: exemples africains”, Journal des africanistes, 58/1, 722.

Simone, Abdoumaliq. 2001. "On the Worlding of African Cities", African Studies Review, 44/2, 1542 .

Tadjo, Véronique and Kathryn Batchelor. 2013. "Translation: Spreading the Wings of Literature" in Kathryn Batchelor and Claire Bisdorff (eds), Intimate Enemies: Translation in Francophone Contexts. Liverpool: Liverpool University Press, 98-108.

Venuti, Lawrence. 1995. The Translator's Invisibility: A history of translation. London: Routledge. 